\title{
TRUST, ICT AND SUPPLY CHAIN COLLABORATION: THE MODERATING ROLE OF COMMITMENT
}

\author{
Kurniawati Arum*, Student \\ Kusmantini Titik, Satmoko Agung, Lecturers \\ Study Program of Management, FEB UPN "Veteran" Yogyakarta, Indonesia \\ *E-mail: arumkurnia09@gmail.com
}

\begin{abstract}
This study aims to analyze the effect of trust and ICT (information and communication technology) on supply chain collaboration with commitment as a moderating variable in the SMEs Screen Printing Yogyakarta City. The variables used in this study are trust, information and communication technology (ICT), commitment, and supply chain collaboration. The data used in this study are primary data. The data collection method used was a questionnaire. Hypothesis testing uses a sample of 48 SMEs in Yogyakarta City. The sampling technique used in this study is incidental sampling and data analysis techniques used is multiple regression analysis and moderated regression analysis. The results of this study indicate that trust has a positive effect on supply chain collaboration, ICT has a positive effect on supply chain collaboration, and commitment is able to strengthen the influence of trust on supply chain collaboration.
\end{abstract}

\section{KEY WORDS}

Supply chain collaboration, trust, ICT, commitment, Screen Printing SMEs.

In the current era of globalization, technological advances are felt increasingly rapid and accompanied by advances in technology-based information systems. Many positive and negative impacts resulting from technological advances. One positive impact of the phenomenon is the potential resulting from creativity in the use of technology. Technological advances provide opportunities for many people to further explore their creativity, to what extent their creativity can be produced through works. It is creativity that triggers the emergence of a creative economy (Ekraf) which is realized in the creative industry. Creative Economy (Ekraf) is one of the sectors that is expected to become a new strength of the national economy that is sustainable, and emphasizes the addition of value to goods through the power of thought and human creativity. According to Howkins (2001), the creative industry is an industry that has characteristics of excellence on the side of creativity in producing or creating various creative designs that are inherent in the products or services produced. Creative Economy (Ekraf) is one of the sectors that is expected to become a new strength of the national economy that is sustainable, and emphasizes the addition of value to goods through the power of thought and human creativity. Today, the creative economy is a catalyst for Indonesia's economic growth amid the slowing global economic growth. The Government of Indonesia in this case the Creative Economy Agency (Bekraf) pays more attention to this sector, with the aim of maximizing the potential and opportunities of the Creative Economy in Indonesia. In 2015 through Presidential Regulation No. 6 of 2015 the Creative Economy Agency (Bekraf) was formed as a non-ministerial government agency responsible for the creative economy with sixteen subsectors namely: architecture, interior design, visual communication design, product design, film, animation and video, photography, crafts, culinary, music, fashion, application and game developers, publishing, advertising, television and radio, performing arts and fine arts.

According bekraf.go.id (2018), the Indonesian Creative Economy business unit in 2016 was dominated by three main sub-sectors namely culinary, fashion, and craft with a culinary subsector percentage of $67.66 \%$, followed by the fashion subsector of $15.01 \%$, and the subsector craft by $14.56 \%$. The three creative economy subsectors with the highest income are culinary $41.40 \%$, followed by fashion $18.01 \%$, and crafts $15.40 \%$ (bekraf.go.id, 2018). 
The contribution of Ekraf to the Gross Domestic Product (GDP) of Indonesia continues to experience growth in each year which is in 2017 reached $7.57 \%$, an increase from 2016 of $7.44 \%$ and in 2015 of $7.39 \%$ (bekraf.go.id in Opus Creative Economy Outlook, 2019). In 2016 the fashion subsector contributed the most to Ekraf's exports by subsector, with a percentage of $54.54 \%$, followed by the craft subsector $39.01 \%$, the culinary subsector $6.31 \%$, and the other subsector $0.14 \%$ (bekraf.go. id, 2018). Based on this value, in addition to culinary, the creative industry of fashion and crafts is a sub-sector of the creative industry which is a priority subsector of the creative economy in Indonesia, because this sub-sector is more resistant to changes in the world economy.

Some creative industry-based SMEs that develop in one of the cities in Yogyakarta, namely Yogyakarta, are SMEs in the fashion and crafts sub-sectors, which in the process of making their products use screen printing techniques. The screen printing technique itself has characteristics and uniqueness in its printing process and requires a high creativity in the design process so that this media is very popular with consumers especially millenials who often have an interest in the uniqueness of product design. The development of creative businesses in the city of Yogyakarta itself can be seen from the many creative products such as screen printing t-shirts, bags, mugs, key chains, handicrafts typical of the city of Yogyakarta, shoes, sandals, trinkets and so on in every corner of the city of Yogyakarta. Yogyakarta City as a student city and one of the leading tourist destinations in Indonesia, of course, causes many newcomers and local and foreign tourists to arrive. Besides culinary, souvenirs that are often hunted are T-shirts, knick-knacks, handicrafts, and other souvenirs. This is one of the opportunities that can be utilized by the Yogyakarta City Screen Printing SMEs to get more income. However, this also shows that Yogyakarta Screen Printing SMEs does not only compete with fellow screen printing businesses but also has to compete with souvenirs and other souvenirs, so that if Screen Printing SMEs are weak in their competitiveness, tourists may begin to forget products with screen printing techniques as one of the mandatory souvenirs typical of the City of Yogyakarta.

The intense competition in the industry in Indonesia, demands creative industry-based SMEs to continue to improve their competitiveness in order to be able to survive in an increasingly competitive market. Likewise, the Yogyakarta City Screen Printing SMEs needs to continue to improve its competitiveness, one of which is by building strong relationships between companies with suppliers and customers or collaborating between supply chain members so as to create a mutually beneficial cooperation relationship. According to Hamidin (2013), one of the requirements that must be met in the implementation of supply chain management is collaboration between entities such as partners in the supply chain system; SMEs themselves, suppliers and distributor. Collaboration between two or more companies can be successful if based on trust (Salam, 2017). According to Mamad and Chahdi (2013), trust is a major factor in building collaboration between supply chain partners. Companies that believe in the integrity of their partners will have a greater intention to continue cooperation with these partners (Wu et al., 2012; Cambra and Polo, 2011). In addition to increasing collaboration, trust is also very important in building commitments among supply chain members, because long-term relationships require commitment from the parties involved. Commitments from supply chain partners will increase collaborative activities and facilitate informative transactions and help avoid conflicts between supply chain partners (Cambra and Polo, 2011; Ryu et al., 2009; Kim et al., 2009).

Information and communication technology (ICT) is also one of the most important aspects in supply chain collaboration. Information and communication technology (ICT) needs to be integrated across companies that collaborate to share information (Salam, 2017). The advantage of ICT is that it will encourage collaboration relationships between ICT-based supply chain partners that enable the creation of fast, accurate, optimal and accountable information sharing. The results of the review of the literature show the importance of trust and information and communication technology (ICT) in supporting supply chain collaboration, as well as the importance of commitment in strengthening the influence of trust on supply chain collaboration. Through trust and high commitment as well as modern and up to date information and communication technology (ICT), it is expected to 
form strong supply chain collaboration, so that it can ultimately improve the competitiveness of creative industry-based SMEs.

\section{THEORY AND HYPOTHESIS}

Anderson and Narus (1990) see trust as a belief that will provide positive results for the organization. Moorman et al. (1993) describe trust as positive beliefs or expectations obtained through exchanges with partners in a supply chain system. According to Mamad and Chahdi (2013), trust is a major factor in building collaboration between supply chain partners. In a supply chain network, one of the most important things for each company to have is trust between organizations (Chopra and Meindl, 2007). Trust is one glue that holds together collaborative relationships (Spekman and Carraway, 2006). Monczka et al. (1998) argue that building trust with suppliers is the most important. Whipple and Frankel (2000) examined the factors influencing the success of the alliance and found that trust was valued as the most important factor by the buyer company and the second most important factor by the supplier company. Zhao and Cavusgil (2006) found important trust for the continuation and improvement of relations. Fawcett et al. (2012) find building collaboration in supply chains is about building trust. Therefore, the third hypothesis states:

$\mathrm{H}_{1}$ : Trust has a positive effect on the supply chain collaboration of Yogyakarta Screen Printing SMEs.

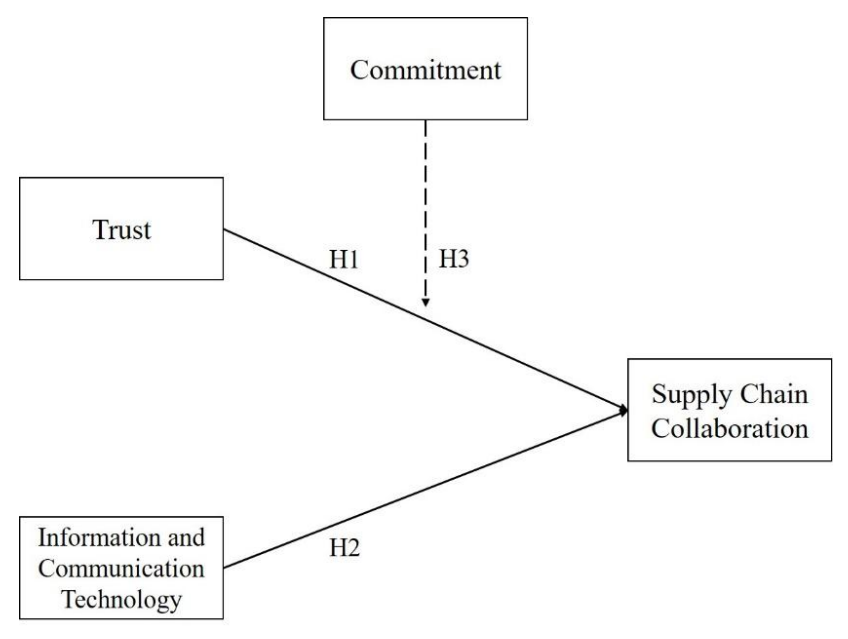

Figure 1 - Causal relationships of research variables

Information and communication technology (ICT) is one of the most important aspects in supply chain collaboration. For supply chain relationships to achieve collaboration, electronic mechanisms must also be in place so that information can be easily exchanged between partners. One such mechanism is the technology for sharing information and communication (Salam, 2017). ICTs have also been shown to support exchanges between trading partners (Pramatari, 2007). Myhr and Spekman (2005) find that collaborative partnerships can be achieved based on trust or electronically mediated exchanges (for example, information and communication technology), because electronic-mediated exchanges help people at the operational level who need current information to carry out their roles effectively, electronic-mediated exchanges are likely to have a direct impact on collaboration. According to Colin et al. (2016) in manufacturing SMEs, the integration of computing systems in the company's operational activities has been very beneficial in handling information, thus improving the decision making process that an entrepreneur must go through to improve organizational development and other benefits including relationships with suppliers because of having more collaboration both and special support agreements that allow them to avoid delays in delivering material resources. Therefore, the second hypothesis states: 
$\mathrm{H}_{2}$ : Information and communication technology (ICT) has a positive effect on the supply chain collaboration of Yogyakarta Screen Printing SMEs.

Companies that believe in the integrity of their partners will have a greater intention to continue cooperation with these partners (Wu et al., 2012; Cambra and Polo, 2011). Trust is also very important in building commitment between members of the supply chain, because long-term relationships require commitment from the parties involved. Commitments from supply chain partners will increase collaborative activities and facilitate informative transactions and help avoid conflicts between supply chain partners (Cambra and Polo, 2011; Ryu et al., 2009; Kim et al., 2009). Therefore, the third hypothesis states:

$\mathrm{H}_{3}$ : Commitment moderates the influence of trust on supply chain collaboration of Yogyakarta Screen Printing SMEs.

\section{METHODS OF RESEARCH}

This type of research is a survey research (survey research), which is the systematic collection of information from respondents with a view to understanding and predicting some aspects of the behavior of the population of interest. The population in this study was 87 Yogyakarta SMEs screen printing which already had an understanding of internet use and had implemented the use of ICT in their operational activities as well as in establishing cooperative relationships with their supply chain partners. The sample selection method in this study is to use the Non Probability Sampling method. The Non Probability Sampling method chosen was incidental sampling, which is a technique of determining samples based on coincidences, ie anyone who accidentally met with the researcher can be used as a sample, if it is deemed that the person met by chance is suitable as a source of data (Sugiyono, 2012: 85).

In this study, the sample taken was 48 Yogyakarta SMEs screen printing. To obtain the data researchers used a questionnaire method. The question asked is a technique that answers the data that is done by giving separate questions or questions raised to respondents to answer (Sugiyono, 2012: 142). The instrument test that was carried out was the validity and reliability test. Validity test used to measure whether the questionnaire used is correct. The question raised is valid if the question raised will be asked. Testing the validity of this study uses validity that correlates the score of each item with the total score which is the sum of each item score. If the significance value is $\alpha \leq 0.05$, then an item is considered valid (Ghozali, 2011). As a reliability test used to find out which measurement results are fixed, measurements are made more than once on the same variations using the same measuring instrument. According to Ghozali (2011) if the Cronbach Alpha value $>0.60$, the items in the questions asked are reliable. And if the Cronbach Alpha value $<0.60$, then the items in the questions asked are not reliable. The data analysis technique in this study is multiple regression analysis to gather information about trustworthiness and ICT in supply chain collaboration and moderation regression analysis to ascertain whether there is a commitment that is able to moderate the commitment to supply chain cooperation.

\section{RESULTS AND DISCUSSION}

From the distribution of questionnaires obtained 48 respondents who have an understanding of the relationship between the company and suppliers and all respondents have filled out the questionnaire completely. The data collected is then used to test the validity and reliability of the instrument. The results of the validity and reliability tests are presented in the following Table 1.

Based on the results of the validity and reliability test, it is known that the significance value of all items in this study is $<0.05$ and Cronbach's alpha value of all variables is $>0.6$, thus it can be concluded that all items in this study are valid and reliable so that it can be used for further analysis. All items that have passed the validity and reliability test are then used to test the research hypothesis. To find out whether a hypothesis is accepted or rejected can be done by looking at the t-statistic value and the significance value. 
Acceptance or rejection of the hypothesis is done by (1) comparing the value of t statistics with $t$ tables and (2) looking at the significance value. To get the value of $t$ table, the first step is to find the number of degrees of freedom (df) using the formula:

$$
\mathrm{df}=\mathrm{n}-\mathrm{k}
$$

Where: $\mathrm{df}=$ degree of freedom; $\mathrm{n}=$ number of samples; $\mathrm{k}=$ number of independent and dependent variables.

Table 1 - Results of Validity Test

\begin{tabular}{|c|c|c|c|}
\hline Item & Pearson Correlation & Significance & \\
\hline $\mathrm{X} 1.1$ & 0.872 & 0.000 & Valid \\
\hline $\mathrm{X} 1.2$ & 0.841 & 0.000 & Valid \\
\hline $\mathrm{X} 1.3$ & 0.873 & 0.000 & Valid \\
\hline $\mathrm{X} 1.4$ & 0.835 & 0.000 & Valid \\
\hline $\mathrm{X} 1.5$ & 0.872 & 0.000 & Valid \\
\hline $\mathrm{X} 2.1$ & 0.870 & 0.000 & Valid \\
\hline $\mathrm{X} 2.2$ & 0.844 & 0.000 & Valid \\
\hline $\mathrm{X} 2.3$ & 0.889 & 0.000 & Valid \\
\hline $\mathrm{X} 2.4$ & 0.860 & 0.000 & Valid \\
\hline $\mathrm{X} 2.5$ & 0.845 & 0.000 & Valid \\
\hline $\mathrm{Z1.1}$ & 0.772 & 0.000 & Valid \\
\hline $\mathrm{Z1.2}$ & 0.863 & 0.000 & Valid \\
\hline Z1.3 & 0.866 & 0.000 & Valid \\
\hline Z1.4 & 0.824 & 0.000 & Valid \\
\hline Y1.1 & 0.754 & 0.000 & Valid \\
\hline Y1.2 & 0.815 & 0.000 & Valid \\
\hline Y1.3 & 0.890 & 0.000 & Valid \\
\hline $\mathrm{Y} 1.4$ & 0.789 & 0.000 & Valid \\
\hline $\mathrm{Y} 1.5$ & 0.867 & 0.000 & Valid \\
\hline Y1.6 & 0.785 & 0.000 & Valid \\
\hline
\end{tabular}

Source: Primary Data Processed, 2019.

Table 2 - Results of Reliability Tests

\begin{tabular}{|l|c|c|}
\hline \multicolumn{1}{|c|}{ Variable } & Cronbach's Alpha & Value \\
\hline Trust & 0,818 & Reliable \\
\hline Information and Communication Technology & 0,818 & Reliable \\
\hline Commitment & 0,824 & Reliable \\
\hline Supply Chain Collaboration & 0,802 & Reliable \\
\hline
\end{tabular}

Source: Primary Data Processed, 2019.

The value of $t$ table with a degree of freedom of 45 for one-tailed test at a significance level of $5 \%$ is 1.6794 so the hypothesis is accepted if the statistical t value $>1.6794$ and the significance value $\leq 0.05$.

Table 3 - Multiple Regression Test

\begin{tabular}{|c|c|c|c|c|c|c|}
\hline \multicolumn{7}{|c|}{ Coefficients $^{a}$} \\
\hline & & \multicolumn{2}{|c|}{ Unstandardized Coefficients } & \multirow{2}{*}{\begin{tabular}{|c|}
$\begin{array}{c}\text { Standardized } \\
\text { Coefficients }\end{array}$ \\
Beta
\end{tabular}} & \multirow[b]{2}{*}{$\mathrm{t}$} & \multirow[b]{2}{*}{ Sig. } \\
\hline \multicolumn{2}{|l|}{ Model } & B & Std. Error & & & \\
\hline \multirow[t]{3}{*}{1} & (Constant) & .670 & .251 & & 2.667 & .011 \\
\hline & Trust & .613 & .096 & .681 & 6.367 & .000 \\
\hline & ICT & .230 & .103 & .240 & 2.241 & .030 \\
\hline \multicolumn{7}{|c|}{ a. Dependent Variable: SCC } \\
\hline \multicolumn{7}{|c|}{ Model Summary } \\
\hline Model & $\mathrm{R}$ & R Square & \multicolumn{2}{|c|}{ Adjusted R Square } & \multicolumn{2}{|c|}{$\begin{array}{l}\text { Std. Error of the } \\
\text { Estimate }\end{array}$} \\
\hline 1 & $.873^{a}$ & .761 & & .751 & & .29047 \\
\hline \multicolumn{5}{|c|}{ a. Predictors: (Constant), ICT, Trust } & & \\
\hline
\end{tabular}

Source: Primary Data Processed, 2019. 
Based on the results of the multiple linear regression analysis presented in Table 3 it can be seen that Trust has a positive influence on supply chain collaboration. This is evidenced by the beta coefficient of 0.681 (positive) with a statistical t value of 6.367 and a significance value of 0.000 , meaning that if trust is high, supply chain collaboration will get better, and thus hypothesis 1 is accepted. ICT (X2) has a positive influence on supply chain collaboration. This is evidenced by the beta coefficient of 0.240 (positive) with a statistical t value of 2.244 and a significance value of 0.030 , meaning that if information and communication technology is good, supply chain collaboration will be better, and thus hypothesis 2 is accepted. The coefficient of determination (R-Square) is 0.761 . This shows that the large percentage of supply chain collaboration can be explained through the trust and ICT variables of $76.1 \%$ and the remaining $23.9 \%$ is explained by other variables outside the research model.

Testing the effect of commitment as a moderating variable on the effect of trust in ICT is carried out in 2 stages, that is:

Table 4 - Simple Regression Test

\begin{tabular}{|c|c|c|c|c|c|c|}
\hline \multicolumn{7}{|c|}{ Coefficients $^{a}$} \\
\hline & & \multicolumn{2}{|c|}{ Unstandardized Coefficients } & \multirow{2}{*}{$\begin{array}{c}\begin{array}{c}\text { Standardized } \\
\text { Coefficients }\end{array} \\
\text { Beta }\end{array}$} & \multirow[b]{2}{*}{$\mathrm{t}$} & \multirow[b]{2}{*}{ Sig. } \\
\hline \multicolumn{2}{|c|}{ Model } & B & Std. Error & & & \\
\hline \multirow[t]{2}{*}{1} & (Constant) & .907 & .237 & & 3.819 & .000 \\
\hline & Trust & .771 & .068 & .85 & 7. $11.291 \mid$ & .000 \\
\hline \multicolumn{7}{|c|}{ a. Dependent Variable: SCC } \\
\hline \multicolumn{7}{|c|}{ Model Summary } \\
\hline Model & $\mathrm{R}$ & R Square & \multicolumn{2}{|c|}{ Adjusted R Square } & \multicolumn{2}{|c|}{$\begin{array}{l}\text { Std. Error of the } \\
\text { Estimate }\end{array}$} \\
\hline 1 & $.857^{\mathrm{a}}$ & .735 & & .729 & & .30290 \\
\hline \multicolumn{5}{|c|}{ a. Predictors: (Constant), Trust } & & \\
\hline
\end{tabular}

Source: Primary Data Processed, 2019.

Table 5 - Moderated Regression Test

\begin{tabular}{|c|c|c|c|c|c|c|c|c|}
\hline \multicolumn{9}{|c|}{ Coefficients $^{a}$} \\
\hline & & & \multicolumn{2}{|c|}{$\begin{array}{c}\text { Unstandardized } \\
\text { Coefficients }\end{array}$} & \multirow{2}{*}{\multicolumn{2}{|c|}{\begin{tabular}{|c|}
$\begin{array}{c}\text { Standardized } \\
\text { Coefficients }\end{array}$ \\
Beta \\
\end{tabular}}} & \multirow[b]{2}{*}{$\mathrm{t}$} & \multirow[b]{2}{*}{ Sig. } \\
\hline \multicolumn{3}{|l|}{ Model } & B & Std. Error & & & & \\
\hline \multirow[t]{4}{*}{1} & \multicolumn{2}{|l|}{ (Constant) } & .652 & .303 & & & 2.152 & .037 \\
\hline & \multicolumn{2}{|l|}{ Trust } & .160 & .109 & & .178 & 1.466 & .150 \\
\hline & \multicolumn{2}{|c|}{ Commitment } & .461 & .118 & & .454 & 3.892 & .000 \\
\hline & \multicolumn{2}{|c|}{ Trust*Commitment } & .047 & .022 & & .349 & 2.082 & .043 \\
\hline \multicolumn{9}{|c|}{ a. Dependent Variable: SCC } \\
\hline \multicolumn{9}{|c|}{ Model Summary } \\
\hline Model & $\mathrm{R}$ & \multicolumn{2}{|c|}{ R Square } & \multicolumn{2}{|c|}{ Adjusted R Square } & \multicolumn{3}{|c|}{$\begin{array}{l}\text { Std. Error of the } \\
\text { Estimate }\end{array}$} \\
\hline 1 & $.942^{\mathrm{a}}$ & & .887 & & .880 & & & .20191 \\
\hline
\end{tabular}

Source: Primary Data Processed, 2019.

Based on a simple regression test to test the direct effect of trust on supply chain collaboration, it is known that the coefficient of determination (R-Square) is 0.735 , meaning that the trust variable influences the supply chain collaboration variable by $73.5 \%$. In the 
moderation regression test, it is known that after the addition of commitment variables, the coefficient of determination (R-Square) increases to 0.887 (88.7\%), meaning that the existence of commitment as a moderating variable is able to strengthen or increase the effect of trust on supply chain collaboration, and with thus hypothesis 3 is accepted.

\section{CONCLUSION}

Based on the results of research that has been done, it can be concluded that trust has a positive effect on supply chain collaboration of Yogyakarta screen printing SMEs, ICT (information and communication technology) has a positive effect on supply chain collaboration of Yogyakarta screen printing SMEs, and commitment is able to moderate the influence of trust on supply chain collaboration of Yogyakarta screen printing SMEs.

Seeing the increasingly fierce competition in the creative industries, the need for Yogyakarta Screen Printing SMEs to continue to improve its competitive advantage in order to be able to continue to survive is to maximize collaboration relationships with supply chain partners. Yogyakarta Screen Printing SMEs needs to continue to foster relationships with its supply chain partners by communicating continuously, exercising ongoing control, making more profitable win-win cooperation contracts, promoting openness of information and sharing information between SMEs and their supply chain partners, maintaining trust with its supply chain partners and maintaining long-term cooperation commitments. Therefore, it is expected that the collaboration between SMEs and their supply chain partners will be better so that it can have a positive impact on increasing the power of Yogyakarta Screen Printing SMEs.

The sample in this study is still quite small namely 48 respondents, it is hoped that further research will be able to expand the research sample (conducted outside the city of Yogyakarta).

Future studies are expected to further evaluate a number of respondents' questionnaire questions because it cannot be denied that misunderstandings can occur in interpreting statement items in questionnaire items. Some respondents sometimes have different understandings in translating a sentence; therefore it is necessary to provide assistance or a brief explanation of the variables used in research.

Further research is expected to be carried out on large local and multinational companies such as FMCG (Fast Moving Consumer Goods) companies but those in Indonesia so as to provide an illustration of whether trust and ICTs also affect supply chain collaboration, and whether commitment can also moderate the influence of trust on supply chain collaboration in large companies in Indonesia.

\section{REFERENCES}

1. Anderson, James C. and James A. Narus, 1990, A model of distributor firm and manufacturing firm working relationships, Journal of Marketing 54(1): 42-58. https://doi.org/10.2307/1252172.

2. Cambra, J. J., Polo Y, 2011, Post-satisfaction factors affecting the long-term orientation of supply relationships, Journal of Business \& Industrial Marketing, 26/6, 395 - 405.

3. Carter, Craig R., Marianne M. Jennings, 2002, Social responsibility and supply chain relationships, Transportation Research, Part E 38 37-52.

4. Chopra, Sunil and Peter Meindl, 2007, Supply Chain Management: Strategy, Planning, and Operation. International Journal of Quality \& Reliability Management, Vol. 20 No. 3, pp. 398-400.

5. Colin, Monica, Raquel Galindo and Octavio Hernandez, 2016, Information and communication technologies, strategy and supply chain management in manufacturing SMEs of Aguascalientes, México, Springer-Verlag Berlin Heidelberg, Ann. Data. Sci. (2016) DOI 10.1007/s40745-016-0071-2.

6. Doney, Patricia M. and Joseph P. Cannon, 1997, An examination of the nature of trust in buyer suppliers relationships, Journal of Marketing, Vol. 61 No 2, pp. 35-51. 
7. Fawcett, Stanley E., Amydee M. Fawcett, Bradlee J. Watson, 2012, Peeking Inside The Black Box: Toward An Understanding Of Supply Chain Collaboration Dynamics, Albers School of Business and Economics, Seattle University, Volume 48, Number 1.

8. Fawcett, Stanley E., Cynthia Wallin And Chad Allred, Amydee M. Fawcett, Gregory M. Magnan, 2011, Information Technology as An Enabler of Supply Chain Collaboration: A Dynamic-Capabilities Perspective, Volume 47, Number 1.

9. Ghozali, Imam, 2011, Aplikasi Analisis Multivariate Dengan Program SPSS, Semarang: Badan Penerbit Universitas Diponegoro.

10. Hamidin, Dini, Akhamad Yunani, and Azizah Zakiah, 2013, Penciptaan Kolaborasi Pada Manajemen Rantai Pasok UKM. Journal and Proceeding FEB Unsoed, Vol. 3 No. 1.

11. Kim, D., Kumar V., Kumar U, 2010, Performance assessment framework for supply chain partnership, Supply Chain Management: An International Journal, 15 (3), 187 - 195.

12. Kwon, Ik-Whan G. and Taewon Suh, 2004, Factors affecting the level of trust and commitment in supply chain relationships, Journal of Supply Chain Management 40(1): 4-14. https://doi. org/10.1111/j.1745-493X.2004.tb00165.x.

13. Mamad, M., Chahdi, F.O., 2013, The Factors of the Collaboration between the Upstream Supply Chain Actors: Case of the Automotive Sector in Morocco, International Business Research, 6 (11), $15-28$.

14. Myhr, Niklas, Robert E. Spekman, 2005, Collaborative supply-chain partnerships built upon trust and electronically mediated exchange, Journal of Business \& Industrial Marketing, Vol. 20 Iss 4/5 pp. $179-186$.

15. Monczka, Robert, Kenneth Petersen, Robert Beaudoin Handfield, and Gary L. Ragatz, 1998, Success factors in strategic supplier alliances: The buying company perspective.Decision Sciences, Vol. 29 No. 3, pp. 553-577.

16. Moorman, Christine, Rohit Deshpande, 1993, Factors affecting trust in market research relationships, Journal of Marketing, Vol. 57, No. 1 (Jan., 1993), pp. 81-101

17. Patterson, Kirk A., Curtis M. Grimm, Thomas M. Corsi, 2003, Adopting new technologies for supply chain manaegement, Transportation Research, Part E 39 95-121.

18. Pramatari, Katerina, 2007, Collaborative supply chain practices and evolving technological approaches. Supply Chain Management: An International Journal, Vol. 12 No 3, pp. 210-220.

19. Russel, Roberta S. and Bernard W. Taylor III, 2011, Operations Management Seventh Edition, United States of America: John Wisley and Sons, Inc.

20. Ryu, I., So S., Koo C, 2009, The role of partnership in supply chain performance, Industrial Management \& Data Systems, 109 (4), 496 -514.

21. Salam, Mohammad Asif, 2017, The mediating role of supply chain collaboration on the relationship between technology, trust and operational performance: an empirical investigation, Benchmarking: An International Journal, Vol. 24 Iss 2 pp, Emerald Group Publishing Limited, http://dx.doi.org/10.1108/BIJ-07-2015-0075.

22. Spekman, R, 2006, Making the transition to collaborative buyer-seller relationships: An emerging framework, Industrial Marketing Management, Vol. 35 No. 1, pp. 10-19.

23. Sugiyono, 2012, Metode Penelitian Kuantitatif, Kualitatif and R\&D, Bandung: Alfabeta.

24. Tripathy, Sushanta, Satyabrata Aich, Anurup Chakraborty, and Gyu M. Lee, 2016, Information technology is an enabling factor affecting supply chain performance in Indian SMEs: A structural equation modelling approach, Journal of Modelling in Management, Vol. 11 Issue: 1, pp.269-287. Emerald Group Publishing Limited.

25. Whipple, Judith M. and Robert Frankel, 2000, Strategic alliance success factors, Journal of Supply Chain, Management, Vol. 36 No. 3, pp. 21-28.

26. Wu, M. et al, 2012, A study of supply chain partnership based on commitment-trust theory. Asia Pacific Journal of Marketing and Logistics, 24 (4),690-707.

27. Zhao, Yushan, S. Tamer Cavusgil, 2006, The effect of supplier's market orientation on manufacturer's trust, Industrial Marketing Management, $35405-414$.

28. bekraf.go.id, 2018, Statistical Data and Results of the Creative Economy Survey.

29. bekraf.go.id, 2018, Opus Creative Economy Outlook 2019.

30. Presidential Regulation Number 6 of 2015. 